\title{
The Relationship Between Selected Marketing Mix and Brand Equity of Ready to Drink (RTD)
}

\author{
Marina Nova Sari ${ }^{1}$, Hartoyo $^{2}$, Nimmi Zulbainarni ${ }^{3}$ \\ ${ }^{1,2,3}$ Management and Business, School of Business, Bogor Agricultural University, Jl Raya Pajajaran, Bogor, Indonesia
}

\begin{abstract}
Half of the middle class income in Indonesia is used to buy fast moving consumer goods (FMCG), especially foods and beverages. The needs of the customers towards beverage ready to drink (RTD) is increasing, along with the shift of beverage function and the change of customer lifestyle. RTD coffee business is becoming more attractive and showing high growth. To face the competition of the industry, companies often use brand-oriented management strategies including Kopiko $78^{0} \mathrm{C}$ as one of the biggest RTD coffee players in Indonesia. A good brand is a brand that has high equity. Brand equity is influenced by the marketing mix and brand equity-forming dimension. This research aimed to know the influence of marketing mix to brand equity through brand equity dimension. The method used was a Structural Equation Models (SEM) with 200 samples. The results showed that marketing mix influenced positively to the brand equity dimension, and all dimensions of brand equity influenced positively and significantly to the brand equity.
\end{abstract}

Keywords: brand equity, marketing mix, ready to drink, structural equation model (SEM).

\section{Introduction}

MARS Indonesia's research shows that $48 \%$ of total middle class income in Indonesia is for fast moving consumer goods (FMCG) especially food and beverage [5]. Consumer demand for ready to drink (RTD) increases with the shift in beverage function and consumer lifestyle changes. Ready to drink are expected to grow an average of $12 \%$ per year. The highest growth of ready to drink is predicted to be ready to drink (RTD) coffee, which is $18.8 \%$ per year [5].

Based on Top Brand Index, RTD coffee market is dominated by five major players namely Granita, Nescafe, Capucini, Kopiko $78^{\circ} \mathrm{C}$, and Good Day. Top Brand Index (TBI) is an award from the brand field through three parameters: market share, commitment share, and mind share. TBI data 2014$2016[19,20,21]$ shows that the value of TBI Kopiko $78^{0} \mathrm{C}$ continues to increase every year. However, the large increase is still below its competitors. Kopiko $78^{\circ} \mathrm{C}$ has not been able to become a market leader in the category of RTD coffee products in Indonesia in accordance with the vision and mission of the company. This indicates that the achievement shown by the Kopiko $78^{\circ} \mathrm{C}$ product has not met expectations.

Companies often devise brand-oriented management strategies to face the competition in the indusrty,. Brand management is crucial as one of the key determinants of corporate success in the marketplace [4]. Consumers will pay attention to brands when making a purchase, reinforcing brands in the minds of consumers is something that should be done by marketers.

A good brand is a brand that has high equity. From a behavioral viewpoint, brand equity is critically important to make points of differentiation that lead to competitive advantages based on nonprice competition [1]. For consumers, a brand with a big name, often used as a reference to choose a product because it promises a higher value. [22] explains that brand equity is affected by the marketing mix through the dimensions of brand equity as described in Figure 1.

Any marketing action has the potential to affect brand equity because it represents the effect of accumulated marketing investments into the brand. For example, [1] list slogans or jingles, symbols, and packages. For this study, we focus on a few key elements of the marketing mix. In particular, we select price, distribution intensity, advertising intensity, and attribute product from the traditional " $4 \mathrm{P}$ " marketing activities (price, place, promotion, and product) as a representative set of marketing programs. Although these variables do not cover the full domain of marketing, they represent typical marketing actions.

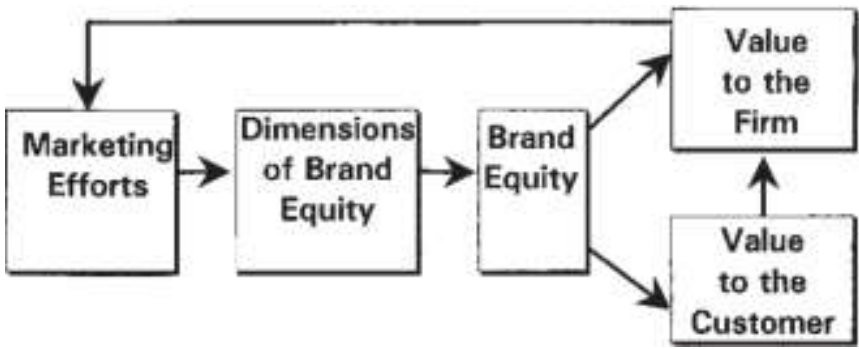

Figure 1: A Conceptual Framework of Brand Equity

Based on the description, the focus of this research is to analyze the relationship between the selected marketing mix with brand equity through brand equity dimensions

\section{Literature Review}

\section{Marketing Mix}

Marketing mix is the combination of the elements of marketing and what roles each element plays in promoting products and services and delivering those products and services to the customers.

Price

According to [10] pricing is very significant in giving value to consumers and influencing product image, as well as 


\section{International Journal of Science and Research (IJSR) \\ ISSN (Online): 2319-7064}

Index Copernicus Value (2016): 79.57 | Impact Factor (2015): 6.391

consumer decision to buy. From the consumer's point of view, prices are often used as an indicator of the value of perceived benefits when consuming goods or services.

\section{Promotion}

According to [17], promotion is a form of marketing communication. Marketing communications are marketing activities that seek to disseminate information, influence / persuade, and / or remind the target market of companies and products to be willing to accept, buy and loyal to the products that the company offers.

\section{Distribution}

Distribution is a variety of activities that companies do to make their products easy to obtain and available to consumers. Distribution is an important variable in the marketing mix to help companies ensure their products reach consumers [9].

\section{Product Attributes}

Product attributes are characteristics or features that may or may not belong to the object [11]. Attributes are everything inherent in the product and become part of the product itself [14].

\section{Brand Equity}

Brand equity is a set of brand assets and liabilities associated with a brand, name, symbol, that can increase or decrease the value provided by a product or service to both the company and the customer [6].

\section{Brand Equity Dimension}

Brand equity dimension consists of perceived quality, association of brand, brand awareness, and brand loyalty. Perceived quality is the comparison between accepted qualities and consumer expectations [12]. The brand association is all the impression that comes to the mind of a person associated with his memory of a brand [6]. Brand awareness refers to whether consumers can recognize and remember brands or not [2]. Brand Loyalty is a measure of customer relationship to a brand. This measure is able to provide an idea of whether or not a customer might switch to another product brand [6].

\section{Methods}

This research was conducted in feb - November 2017. The research conducted in Bogor City which is divided into six districts. The districts are North Bogor, South Bogor, East Bogor, Central Bogor, West Bogor, and Tanah Sereal. The data collected is processed with descriptive method through interview with questionnaire.

There were 200 respondents in this research. The respondents of this research were consumers who consumed RTD Kopiko $78^{\circ} \mathrm{C}$ in the last 3 months. The sampling technique used was multistage non-probability sampling with purposive and convenience sampling approach. The data obtained were analysed using descriptive analysis and Structural Equation Modelling (SEM).

\section{Result}

The data obtained were processed using two analytical methods, which were descriptive analysis and Structural Equation Modelling (SEM). Descriptive analysis used to describe the profile of respondents. SEM through LISREL application used to explain relationship between marketing mix with brand equity dimention and brand equity.

\subsection{Descriptive Analysis}

Descriptive analysis provides information on demographic characteristics of respondents. The analysis showed that the age group of respondents was $17-25$ years $(65 \%)$. The majority of respondents were dominated by female (55\%). The education level of respondents was dominated by undergraduate level $(62.5 \%)$ and has at least a primary school education $(0.5 \%)$. The majority of respondents occupations were private employees $(36.5 \%)$ and college students $(31 \%)$ with total household expenditure per month dominated > Rp 2500000 (55\%).

The majority of respondents have become consumers of RTD coffee $>6$ months $(65 \%)$. Respondents purchased at most $<3$ bottles per week $(85.5 \%)$. The most frequent place for RTD coffee purchased by respondents is minimarket (83\%). Factors that affect consumers to consume coffee RTD are themselves $(46 \%)$. Personal characteristics that can influence purchasing decisions include age, life-cycle stage, occupation, economic circumstances, lifestyle, personality, and self-concept of the buyer [15].

\subsection{Measurement Model}

The measurement model describes the relationship between the indicator variable and the latent variable on the SEM model through the reliability test. According to [8], the reliability test is the process of measuring the accuracy (consistency) of an instrument. This test is intended to ensure the instrument used is a reliable, consistency, stable and dependibalitas instrument. To test the reliability of the data, this research used indicator based on the Variance Extracted (VE) and Construct Reliability (CR) presented in Table 1.

The Variance Extracted (VE) value was used to measure the number of variants that can be captured by the construct compared to the variance caused by measurement error. While the value of composite reliability (CR) showed the consistency of each indicator in measuring the construct. The higher the value of composite reliability (CR) the more consistent the indicator in measuring the construct. [17] explains that the indicator of the variable is called reliable if the value of $\mathrm{VE} \geq 0.05$ and $\mathrm{CR} \geq 0.07$. The results of processing in Table 1 show that all values of construct reliability (CR) and variance extracted (VE) in this study are above 0.70 and 0.50 , so it can be concluded that the models in this study are reliable for use. 


\section{International Journal of Science and Research (IJSR) ISSN (Online): 2319-7064}

Index Copernicus Value (2016): 79.57 | Impact Factor (2015): 6.391

Table 1 : Operational Measures and Scale Reliability Values

\begin{tabular}{|c|c|c|c|}
\hline \multicolumn{2}{|c|}{ Item } & \multirow{3}{*}{$\begin{array}{c}\text { Standardized Loading } \\
0.87\end{array}$} & \multirow{2}{*}{$\mid t$-value } \\
\hline Price $(\mathrm{Cl}$ & $=0.85 ; \mathrm{VE}=0.74)^{\mathrm{a}}$ & & \\
\hline P1 & Price $\mathrm{X}$ is according to the quality presented & & 15.6 \\
\hline $\mathrm{P} 2$ & Price $\mathrm{X}$ is affordable & 0.76 & 15.39 \\
\hline \multicolumn{4}{|c|}{ Distribution Intensity $(\mathrm{CR}=0.82 ; \mathrm{VE}=0.61)^{\mathrm{a}}$} \\
\hline D1 & Many stores / supermarkets sell X & 0.67 & 13.83 \\
\hline D2 & X easily obtained than other brands & 0.58 & 15.13 \\
\hline D3 & $\mathrm{X}$ is always available in stores / supermarkets & 0.93 & 20.02 \\
\hline \multicolumn{4}{|c|}{ Advertising intensity $(\mathrm{CR}=0.82 ; \mathrm{VE}=0.6)^{\mathrm{a}}$} \\
\hline IK1 & $\mathrm{X}$ ads are very often aired on the internet, print media, and TV & 0.78 & 9.04 \\
\hline IK2 & X often sponsors major events & 0.73 & 6.7 \\
\hline IK3 & It looks like $\mathrm{X}$ advertising spend is bigger than other brands & 0.71 & 9.66 \\
\hline \multicolumn{4}{|c|}{ Product attributes $(\mathrm{CR}=0.91 ; \mathrm{VE}=0.77)^{\mathrm{a}}$} \\
\hline AP1 & I was able to distinguish $\mathrm{X}$ from other brands through logo only & 0.74 & 11.76 \\
\hline AP2 & I bought $X$ because of its taste & 0.88 & 12.36 \\
\hline AP3 & $\mathrm{X}$ packaging reflects the high quality of the product & 1.00 & 23.63 \\
\hline \multicolumn{4}{|c|}{ Perceived quality $(\mathrm{CR}=0.8 ; \mathrm{VE}=0.58)^{\mathrm{a}}$} \\
\hline KK1 & $\mathrm{X}$ has high quality & 0.94 & 11.2 \\
\hline KK2 & $\mathrm{X}$ is produced with high technology & 0.67 & 12.44 \\
\hline KK3 & I believe $\mathrm{X}$ is safe for my health and my family & 0.65 & 11.92 \\
\hline \multicolumn{4}{|c|}{ Brand Associations \& Awareness $(\mathrm{CR}=0.92 ; \mathrm{VE}=0.79)^{\mathrm{a}}$} \\
\hline KA1 & I can differentiate $\mathrm{X}$ with other brands & 0.69 & 17.35 \\
\hline KA2 & Familiar with $\mathrm{X}$ & 0.99 & 9.78 \\
\hline KA3 & $\mathrm{X}$ gives a positive impression & 0.95 & 10.38 \\
\hline \multicolumn{4}{|c|}{ Brand Loyalty $(\mathrm{CR}=0.86 ; \mathrm{VE}=0.67)^{\mathrm{a}}$} \\
\hline L1 & I would recommend $\mathrm{X}$ to my friends or relatives & 0.8 & 12.46 \\
\hline L2 & I will not buy another brand if $\mathrm{X}$ is not in the store & 0.62 & 8.47 \\
\hline L3 & Loyal consumers to $\mathrm{X}$ & 1.00 & 12.25 \\
\hline \multicolumn{4}{|c|}{ Brand Equity $(\mathrm{CR}=0.94 ; \mathrm{VE}=0.89)^{\mathrm{a}}$} \\
\hline E1 & $\mathrm{X}$ will be my first and foremost choice & 1.00 & 9.68 \\
\hline E2 & $\mathrm{X}$ is the best brand of coffee drink & 0.88 & 16.95 \\
\hline
\end{tabular}

a. Value of construct reliability (CR) and variance extracted (VE)

b. Goodness-of-fit statistics of the measurement model of 22 indicators for eight constructs are as follows: Root Mean Square Error of Approximation $($ RMSEA $)=0.078$, Goodness-of-Fit Index $(\mathrm{GFI})=0.96$, Adjusted Goodness-of-Fit Index $($ AGFI $)=0.93$, Normed Fit Index $(\mathrm{NFI})=0.95$, Comparative Fit Index $(\mathrm{CFI})=0.97$, and Incremental Fit Index $(\mathrm{IFI})=0.97$.

c. $\mathrm{X}=$ the focal brand

In general, goodness of fit is defined as how well the existing model mimics the covariance matrix among the indicators. The smaller the difference between the estimated covariance matrix with the observed covariance matrix, the more fit the model [13]. This study uses 6 test criteria, namely RMSEA, GFI, AGFI, IFI, NFI, and CFI. Goodness of fit test results can be seen in table 1 . The results show the criteria of RMSEA generating value $0.078 \leq 0.08$ which means that the resulting model is good fit. Other goodness of fit criteria are GFI, AGFI, IFI, NFI and CFI yield values> 0.90. Since all criteria are met, the resulting model has goodness of fit and the model can be used to explain the relationships between variables in the model.

The standardized loading values and t-value are used to explain the relationship between the indicator variable and the latent variable. VE, CR, loading factor, and t-value are presented in Table 1. T-value shows the significance of the relationship between the indicator variable and the latent variable. Relationships are significant if they have $\mid \mathrm{t}$-value $\mid>$ 1.96. The results in table 1 show all $\mid \mathrm{t}$-value $\mid>1.96$, it is concluded that all indicator variables significantly influence the latent variables.

The standardized loading value shows the contribution of the indicator variable to explain the latent variable. The larger the standardized loading value the greater the contribution of the indicator variable to the latent variable. The indicator with the highest contribution to explain the price is $\mathrm{P} 1$, indicating that consumers of Kopiko $78^{\circ} \mathrm{C}$ prioritize product quality before price. The highest contribute indicator for explaining the distribution is D3, so it is important to maintain the availability of products in various stalls / minimarkets / supermarkets.

The results show that the highest contribute indicator for explaining the intensity of advertising is IK1, indicating that it is necessary to serve advertising on the internet, print media, and TV. The highest contribute indicator for explaining product attributes is AP3. That mean the attributes of products that consumers pay attention to is packaging. The indicators with the highest contribution to explain the impression of quality, loyalty, association and brand awareness are KK1, KA2 and L3, while the indicator with the highest contribution to explain the brand equity is E1. To establish brand equity, the main thing to consider is how to make the Kopiko $78^{\circ} \mathrm{C}$ a top choice for consumers.

\subsection{Structural Model}

The structural model describes the relationship between latent variables in the model, ie the relationship between

\section{Volume 6 Issue 12, December 2017}




\section{International Journal of Science and Research (IJSR) \\ ISSN (Online): 2319-7064}

Index Copernicus Value (2016): 79.57 | Impact Factor (2015): 6.391

brand equity dimension and brand equity and the relationship between the marketing mix and the brand equity dimension.

Table 2 : Structural Model Estimates

\begin{tabular}{|c|c|c|c|}
\hline Relationship of Hypothesis & Standardized Loading & |t-value & Conclusion \\
\hline \multicolumn{4}{|l|}{ The relationship between the dimensions of brand equity and brand equity } \\
\hline Hypothesis 1:Perceived Quality $\rightarrow$ Brand Equity ${ }^{(+)}$ & 0.40 & $5.67 *$ & Supported \\
\hline Hypothesis 2:Brand awareness / association $\rightarrow$ Brand Equity ${ }^{(+)}$ & 0.42 & $4.61 *$ & Supported \\
\hline Hypothesis 3:Brand Loyalty $\rightarrow$ Brand Equity ${ }^{(+)}$ & 0.81 & $6.29 *$ & Supported \\
\hline \multicolumn{4}{|l|}{ The relationship between the marketing mix and the brand equity dimension } \\
\hline Hypothesis 4:Price $\rightarrow$ Perceived Quality ${ }^{(+)}$ & 0.46 & $3.80 *$ & Supported \\
\hline Hypothesis 5:Distribution $\rightarrow$ Perceived Quality ${ }^{(+)}$ & 0.12 & 1.35 & Supported \\
\hline Hypothesis 6:Product Attributes $\rightarrow$ Perceived Quality ${ }^{(+)}$ & 0.53 & $6.43^{*}$ & Supported \\
\hline$\underset{(+)}{\text { Hypothesis 7:Distribution intensity } \rightarrow \text { Awareness \& Brand Associaton }}$ & 0.30 & $6.10^{*}$ & Supported \\
\hline Hypothesis 8:Advertising intensity $\rightarrow$ Awareness \& Brand Associaton ${ }^{(+)}$ & 0.62 & $10.16^{*}$ & Supported \\
\hline Hypothesis 9:Product Attributes $\rightarrow$ Awareness \& Brand Associaton ${ }^{(+)}$ & 0.37 & $7.12 *$ & Supported \\
\hline Hypothesis 10:Price $\rightarrow$ Brand Loyalty ${ }^{(+)}$ & 0.25 & $2.67 *$ & Supported \\
\hline Hypothesis 11:Distribution $\rightarrow$ Brand Loyalty ${ }^{(+)}$ & 0.60 & $13.89 *$ & Supported \\
\hline Hypothesis 12:Advertising intensity $\rightarrow$ Brand Loyalty ${ }^{(+)}$ & 0.10 & 0.37 & Supported \\
\hline
\end{tabular}

*) show $|t-h i t|>1.96$ or significant

${ }^{(+)}$Hypothesized direction of effect.

The relationship between the dimensions of brand equity and brand equity. The results show that all dimensions of brand equity have a positive and significant influence on brand equity formation. This is indicated by all positive standardized loading values and $\mathrm{t}$-values that show $\mid \mathrm{t}$-value p 1.96. This is in accordance with the statement [3] that the three dimensions in brand equity, namely brand loyalty, perceived quality, brand awareness, and brand association have a positive influence on brand equity and they can be an indicator of product quality. The dimension with the greatest influence to form brand equity is the dimension of brand loyalty with a standardized loading value of 0.81 shown in table 2 . That mean if you want to increase brand equity, the dimension of brand loyalty becomes the main thing that must be continuously managed and improved.

The relationship between the marketing mix and the brand equity dimension. The relationship of each marketing mix element to brand equity is mediated by brand equity dimensions. Because every brand equity dimension contributes positively to brand equity, if a marketing mix affects brand equity dimensions positively, it is expected to lead to an increase in brand equity. The entire marketing mix has a positive relationship with the brand equity dimension. According to this analysis, high advertising intensity, high distribution intensity, and improvement of product attribute quality are examples of brand-building activity.

Distribution. Distribution intensity is also highly correlated with brand equity. Marketing mix variables with the highest contribution to increase brand loyalty is the distribution with the value of standardized loading of 0.60 . Thus, to increase brand equity, improve the distribution strategy are important thing to do. This is in accordance with the statement [22], that the more evenly distributed it will increase brand loyalty.

Product attributes. Based on [16], product attributes positively affect the dimension of brand equity in the form of perceived quality. This is in accordance with the results of the research in Table 2 which shows that marketing mix variables with the highest contribution to form the perceived quality is the product attribute with the value of standardized loading of 0.53 . Thus, to improve the perceived quality, appropriate innovation is needed to attribute products such as packaging, logo, color, etc.

Advertising Intensity. Advertising is the marketing mix variable with the highest contribution to form association and brand awareness with a standardized loading value of 0.62 . Thus, if you want to improve association and brand awareness, advertising is the thing that needs to be done. Advertising have an important role in improving brand association and awareness. Advertising that run continuously will make consumers aware of the existence of brands and encourage consumers to buy brands that air. [22]. When consumers see high advertising spending, it will contribute to their perception of the level of confidence in the product. Advertising spending has a positive effect on the impression of quality, association and brand loyalty [22].

Price. Price is the only one marketing mix variable that does not have the highest contribution to any brand equity dimension. However, based on Table 2, prices have contributed to form perceived quality with a factor loading rate of 0.46 . This is in accordance with the opinion [16] which suggests that the expensive price is perceived to have high quality, while the low price is perceived to have a low quality. Brand equity may decrease when consumers strongly relate price to product quality. Consumers may perceive that a lower price is made by cutting costs and product quality to maintain profit margins. If possible, managers should avoid frequent price cuts or a consistent low-price strategy, because they lower perceived quality and product image. While maintaining the price level, managers can capitalize on technological progress, managerial efficiency, and customer service to enhance the value of the product.

\section{Volume 6 Issue 12, December 2017}




\section{International Journal of Science and Research (IJSR) \\ ISSN (Online): 2319-7064}

Index Copernicus Value (2016): 79.57 | Impact Factor (2015): 6.391

\section{Conclusion and Suggestion}

\subsection{Conslusion}

Price has a positive and significant effect on the perceived quality. Distribution positively and significantly affects perceived quality, association, awareness, and brand loyalty. Advertising intensity positively and significantly affects the association and brand awareness. Advertising intensity positively and insignificantly affects brand loyalty. The relationship of all dimensions of brand equity to brand equity was positive and significant. The order of brand equity dimensions from the highest to lowest impact on brand equity are brand loyalty, brand awareness, association, and brand quality impressions.

\subsection{Suggestions}

This study has limitations that need to be improve such as, research using indicator variables more diverse so that the model's ability to explain the brand equity becomes greater. Besides that, research needs to be done on the relationship between the marketing mix to brand equity directly. According to this research, managers should invest in advertising, distribution, and inovation of product attribute to develop brand equity of ready to drink (RTD).

\section{References}

[1] Aaker D. 1991. Managing Brand Equity, Capitalizing on the Value of a Brand Name. New York(US): The Free Press.

[2] Barroso A, llobet G. 2012. Advertising and consumer awareness of new, differentiated products. Journal of Marketing Research. 9(6):773-792.

[3] Beristain J, zorrilla P. 2011. The relationship between store image and store brand equity: A conceptual framework and evidence from hypermarkets. Journal of Retailing and Consumer Services. 18:62-574.

[4] Budac C, baltador L. 2013. The value of brand equity. Procedia Economics and Finance. 6:444-448.

[5] [DI] Dunia Industri. 2015. Penjualan packaged food dan minuman ringan tumbuh paling tinggi [Internet]. [diacu 2017 Januari 15]. Tersedia pada : http://duniaindustri.com/penjualan-packaged-food-danminuman-ringan-tumbuh-paling-tinggi/

[6] Durianto D, sugiarto, sitinjak T. 2001. Strategi Menaklukan Pasar Melalui Riset Ekuitas dan Perilaku Merek. Jakarta(ID): Penerbit PT Gramedia Pustaka Utama.

[7] Goi CL. 2009. A review of marketing mix: 4P or more?. International Journal of Marketing Studies. 1(1):313318.

[8] Hosseini MH, moezzi H. 2015. Exploring impact of marketing mix on brand equity in isurance industry (case study: asia insurance firm, iran). Journal of Asian Scientific Research. 5(1):38-45.

[9] Kotler P. 2009. Manajemen Pemasaran : Analisis, Perencanaan, Implementasi dan Pengendalian Edisi ke2. Jakarta(ID): Erlangga.
[10] Lupiyoadi R. 2011. Manajemen Pemasaran Jasa Teori dan Praktik. Jakarta(ID): Penerbit Salemba Empat.

[11] Mowen J, michael M. 2002. Perilaku Konsumen. Jakarta(ID): Erlangga.

[12] Ranjbarian B, sanayei A, kaboli MR, and hadadian A. 2012. An analysis of brand image, perceived quality, customer satisfaction and repurchase intention in Iranian department stores. International Journal of Scientific and Research Publications. 7(6): 40-45.

[13] Santoso, singgih. 2011. Structural Equation Modeling (SEM) Konsep dan Aplikasi dengan AMOS 18. Jakarta(ID): Penerbit PT Elex Media Komputindo.

[14] Simamora B. 2003. Aura Merek. Jakarta(ID): PT Gramedia Pustaka Utama.

[15] Sumarwan U. 2011. Perilaku Konsumen Teori dan Penerapannya dalam Pemasaran. Bogor (ID): Ghalia Indonesia.

[16] Sumarwan U, Djunaidi A, Aviliani, Singgih R, Sayono JA, Budidarmo RR, Rambe S. 2009. Pemasaran Strategik, Strategi Untuk Pertumbuhan Dalam Pemnciptaan Nilai Bagi Pemegang Saham. Jakarta Timur (ID): Inti Prima.

[17] Tjiptono F. 1997. Strategi Pemasaran. Yogyakarta(ID): ANDI Yogyakarta.

[18] Tjiptono F, anastasia D. 2000. Prinsip dan Dinamika Pemasaran. Yogyakarta(ID): Penerbit J\&J Learning.

[19] TOP Brand. 2014-2016. Top brand index 2014 fase 2 [Internet]. [diacu 2017 Januari 17]. Tersedia pada http://www.topbrand-award.com/topbrandsurveysurveyresult/top_brand_index_2014_fase_2

[20] TOP Brand. 2015. Top brand index 2015 fase 2 [Internet]. [diacu 2017 Januari 17]. Tersedia pada : http://www.topbrand-award.com/top-brandsurvey/survey-result/top_brand_index_2015_fase_2

[21] TOP Brand. 2016. Top brand index 2016 fase 2 [Internet]. [diacu 2017 Januari 17]. Tersedia pada : http://www.topbrand-award.com/top-brandsurvey/survey-result/top_brand_index_2016_fase_2

[22] Yoo B, naveen D, sungho L. 2000. An examination of selected marketing mix elements and brand equity. Journal of the Academy of Marketing Science. 28(2):195-211.

\section{Author Profile}

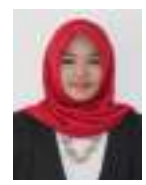

Marina Nova Sari received the bachelor degree in Management of Forest, Forest Faculty of Bogor Agricultural University in 2015 as "Honors" predicate wih Forest major. She continued her study in Management and Business, School of Business at Bogor Agricultural University from 2016.

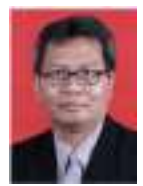

Hartoyo received the bachelor degree (1986) in agribusiness science, Bogor Agricultural University $\mathrm{He}$ received master degree (1991) in consumer sciences from Virginia Tech, USA. He has been honored getting the doctor (1998) in family economics from Virginia Tech, USA. He is a lecturer in School of Business (bachelor, master, and doctoral programs), Bogor Agricultural University. 


\section{International Journal of Science and Research (IJSR) \\ ISSN (Online): 2319-7064}

Index Copernicus Value (2016): 79.57 | Impact Factor (2015): 6.391

Nimmi Zulbainarni received the bachelor degree (1997) in socio-economic fisheries, Bogor Agricultural University. She received master degree (2002) in agricultural economics sciences, Bogor Agricultural University. She participated in the non degree scholarship program for short term student exchange (2003) in Kagoshima University, Japan. She has been honored getting the doctor (2011) in agricultural economics, Bogor Agricultural University. She is a lecturer in Department of Fishery Resources Utilization (bachelor, master, and doctoral programs) Faculty of Fisheries and Marine Science, and School of Business, Bogor Agricultural University.

Volume 6 Issue 12, December 2017

www.ijsr.net 